\title{
HUKUM PINJAM PAKAI BARANG BUKTI HASIL TINDAK PIDANA PENCURIAN
}

\author{
Atik Unasikah \\ atik_unasikah@gmail.com \\ RT. 06 RW.01 Gandekan Wonodadi \\ Blitar
}

\begin{abstract}
This article discusses the Islamic law perspective on the procedures and the legal basis of the leasing evidence of a criminal act of theft in the Police Sector of the District of Wonocolo-Surabaya. The prosedures of leasing evidence of a criminal act of theft in the Police Sector of the District of Wonocolo-Surabaya are by making a request in a written form, completing the term of application, considering the request of the applicant by the investigator, and the approval of the Police Sector chief. The legal basis used is the Criminal Procedure Code Article 45, Paragraph 1 (one), namely: the consideration of the investigators on the evidence used beyond the trial period, the owner is in need, and complated with the waiver or agreement. In Islamic law, leasing evidence of a criminal act of theft in the Police Sector of Wonocolo-Surabaya is permissible (mubâh). The reason is that the applicant is desperately in need of these goods for daily needs. Moreover the borrower is the owner himself. Although the evidence is important but the human need is more important.
\end{abstract}

Keywords: Leasing of goods, evidence of the offense, theft, Islamic law.

Abstrak: Artikel ini membahas tentang prosedur dan dasar hukum pinjam pakai barang bukti hasil tindak pidana pencurian, serta pandangan hukum Islam terhadap pinjam pakai barang bukti hasil tindak pidana pencurian di Polsek Kecamatan Wonocolo Kota Surabaya. Prosedur pinjam pakai barang bukti pencurian hasil tindak pidana pencurian di Polsek Kecamatan Wonocolo Kota Surabaya adalah membuat surat permohonan, melengkapi syarat-syarat permohonan, penyidik mempertimbangkan permohonan pemohon, dan persetujuan Kapolsek. Dasar hukum yang digunakan adalah KUHAP pasal 45 ayat 1 , dan pertimbangan-pertimbangan penyidik adalah barang bukti tersebut digunakan diluar waktu persidangan, pemilik sangat membutuhkan, dan ada surat pernyataan atau perjanjian. Dalam hukum Islam, pinjam pakai barang bukti hasil tindak pidana pencurian di Polsek Wonocolo Kota Surabaya adalah mubâh (boleh), karena melihat alasan pemohon yang sangat membutuhkan barang tersebut untuk kebutuhannya sehari-hari apalagi yang meminjam adalah pemilik sendiri. Walaupun keberadaan barang bukti adalah penting tetapi kebutuhan manusia lebih penting.

Kata Kunci: Pinjam pakai. barang bukti, pencurian, hukum Islam 


\section{Pendahuluan}

Bangsa Indonesia adalah bangsa yang heterogen. Di dalamnya terdapat keanekaragaman suku, budaya, adat, dan lain sebagainya, yang terbentang dari Sabang sampai Merauke. Dalam kehidupan, masyarakat selalu mengalami perubahan dari masa ke masa, hal ini bisa dilihat dari gaya hidup masyarakatnya sehari-hari. Dalam bidang transportasi misalnya, dahulu orang memanfaatkan tenaga hewan sebagai alat transportasi seperti; pedati, andong, gerobak, delman dan lain-lain. Seiring dengan perkembangan teknologi modern, maka terciptalah kendaraan bermotor, mobil, kereta api, pesawat terbang dan lain-lain yang telah menggunakan tenaga mesin. Semakin pesat perkembangan teknologi tanpa diikuti dengan peningkatan kesejahteraan masyarakat, dapat menimbulkan dampak negatif, salah satunya adalah semakin banyaknya pencurian.

Pencurian merupakan bentuk kejahatan terhadap benda. Tindak pidana pencurian telah diatur dalam KUHP pasal 362, di dalamnya dijelaskan bahwa, "Barangsiapa mengambil suatu barang, yang sama sekali atau sebagian termasuk kepunyaan orang lain, dengan maksud akan memiliki barang itu dengan melawan hak, dihukum karena pencurian, dengan hukuman penjara selama-lamanya lima tahun atau denda sebanyak-banyaknya Rp. 900,-”. 1

Motif yang melatarbelakangi tindak pidana pencurian lebih banyak adalah karena faktor ekonomi, sehingga modus operandi yang digunakan juga bermacam-macam, mulai dari menggunakan alat sederhana seperti kunci letter $\mathrm{T}$ sampai dengan menggunakan kekuatan magis dengan cara melakukan gendam. Hal ini menuntut peran serta pihak kepolisian untuk meningkatkan profesionalisme Polri.

Dalam menjalankan tugasnya, Polri dituntut untuk bersikap secara profesional dalam menangani kejahatan yang terjadi di masyarakat. Tingkat kejahatan antar tiap daerah berbeda, apalagi di kota besar seperti kota Surabaya, tingkat kejahatan yang ditangani juga besar. Keadaan seperti ini membuat barang bukti yang ditemukan juga semakin banyak.

Barang bukti adalah barang-barang baik yang berwujud, bergerak atau tidak bergerak yang dapat dijadikan bukti dan fungsinya untuk diperlihatkan kepada terdakwa maupun kepada saksi di persidangan

${ }^{1}$ R. Soesilo, Kitab Undang-Undang Hukum Pidana (KUHP) (Bogor: Politeia, t.th), 249. 
guna mempertebal keyakinan hakim dan menentukan kesalahan terdakwa. $^{2}$

Barang bukti sebagai hasil dari benda sitaan seringkali membuat repot, apalagi barang-barang yang cepat rusak, motor misalnya, karena selain membutuhkan tempat yang luas, perawatan barang-barang sitaan juga perlu diperhatikan. Untuk menyiasati terjadinya penyimpangan, pemilik barang sitaan (barang bukti) diberi kesempatan untuk menggunakan barang tersebut, dengan cara "pinjam pakai". Fakta di lapangan ditemukan bahwa di Polsek Kecamatan Wonocolo Kota Surabaya terdapat warga yang melakukan praktek pinjam pakai, seperti yang dilakukan Bapak Cakiyadin (28) dengan alamat Bendul Merisi IX/17-C. Beliau melakukan pinjam pakai terhadap sepeda motor merek Yamaha Yupiter Z warna merah hitam, pada tahun 2008. Pada dasarnya prosedur pinjam pakai cukup mudah, yakni dengan mengajukan permohonan kepada kasat atau kadit serse, dengan melampirkan bukti kepemilikan barang tersebut. Dengan cara ini, barang-barang sitaan menjadi lebih terawat dan bermanfaat. Namun, hal ini bukan berarti melegalisasi bahwa barang tersebut sudah berpindah tangan ke orang tersebut. Itu sebabnya, pemohon pinjam pakai diwajibkan mengisi surat pernyataan bahwa mereka bersedia menghadirkan barang bukti tersebut pada saat dibutuhkan untuk bukti di persidangan ${ }^{3}$.

Dalam praktek persidangan alat-alat bukti yang digunakan menurut pasal 184 KUHAP ialah:
a. Keterangan saksi
b. Keterangan ahli
c. Surat
d. Petunjuk
e. Keterangan terdakwa. ${ }^{4}$

Praktek pinjam pakai barang bukti ini memang tidak dibenarkan oleh hukum dan tidak diatur dalam peraturan perundang-undangan bahkan hal ini juga bertentangan dengan ketentuan yang terdapat dalam pasal 44 ayat (2) KUHAP:

"Penyimpanan benda sitaan dilaksanakan dengan sebaik-baiknya dan tanggung jawab atasnya ada pada pejabat yang berwenang

\footnotetext{
2 Djoko Prakoso, Alat Bukti dan Kekuatan Pembuktian di dalam Proses Pidana (Yogyakarta: Liberty, 1988), 148.

${ }^{3} \mathrm{http} / /$ www.sinarharapan.co.id

${ }^{4}$ Andi Hamzah, Hukum Acara Pidana Indonesia (Jakarta; Sinar Grafika, 1993), 255.
} 
sesuai dengan tingkat pemeriksaan dalam proses peradilan dan benda tersebut dilarang untuk dipergunakan oleh siapapun juga." 5

Artinya, barang bukti yang ada baik di tingkat kepolisian, kejaksaan, tidak dapat dipergunakan sebelum mendapatkan putusan pengadilan dan memiliki kekuatan hukum yang bersifat tetap. Hal ini dikhawatirkan apabila barang bukti tersebut dipindahtangankan maka bisa merubah bentuk barang dari saat pertama kali barang bukti itu ditemukan. Karena dalam proses peradilan, fungsi barang bukti ini sangat penting yaitu sebagai sarana pembuktian untuk memperkuat keyakinan hakim dalam memeriksa dan memutus suatu perkara. ${ }^{6}$

KUHAP tidak mengatur sanksi terhadap pelanggaran ketentuan tersebut karena bukanlah pada tempatnya KUHAP yang mengatur hukum acara juga mengatur sanksi. Secara administratif, sanksi terhadap pelanggaran Pasal 44 KUHAP diatur oleh instansi penyidik (misalnya kepolisian) atau instansi penuntut umum (kejaksaan) dalam bentuk peraturan KaPolri atau peraturan Jaksa Agung. Kalau pelanggaran tersebut bersifat pidana, seperti penggelapan barang bukti, sudah tentu berlaku ketentuan pidana seperti diatur pada Kitab Undang-Undang Hukum Pidana. Pasal 44 KUHAP juga mengatur bahwa benda sitaan disimpan dalam rumah penyimpanan benda sitaan negara (RUPBASAN). Lembaga inilah yang memelihara keutuhan benda sitaan dan barang rampasan baik kualitas maupun kuantitasnya, menjamin keselamatan dan keamanan benda yang disita untuk menjadi barang bukti pada proses penyidikan, penuntutan, dan persidangan.

Pembuktian dalam Islam di kenal dengan istilah "al-Bayyinah".

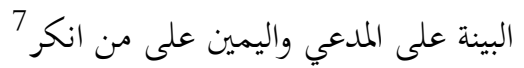

"Bukti menjadi kewajiban si penggugat, sedang sumpah menjadi

kewajiban si tergugat."

Dalil di atas dapat dijadikan dasar bahwa pembuktian bukan saja bisa dari unsur manusia sebagai saksi saja, akan tetapi unsur benda pun dapat dijadikan sebagai dasar penuntutan untuk selanjutnya benda itu diajukan di muka sidang pengadilan untuk mendapatkan keterangan yang sebenar-benarnya dari terdakwa atau saksi.

\footnotetext{
${ }^{5}$ Kitab Undang-Undang Hukum Acara Pidana (Surabaya: Karya Anda, t.th.), 26.

${ }^{6}$ Djoko Prakoso, Alat Bukti dan Kekuatan Pembuktian di dalam Proses Pidana, 146.

${ }^{7}$ Abdul Rahman As-Suyuti, Jâmi' Sagîr (Indonesia: Dār al-lhya' al-Kitāb al-'Arabiyyah, t.t.), 220.
} 
Barang yang dijadikan sebagai bukti di pengadilan wajib disimpan dan jaga sebaik-baiknya, karena mengingat fungsi barang bukti ini sangat penting sebagai hujjah di persidangan nanti. Hal ini sesuai dengan $\mathrm{Al}$ Qur'an Surat An-Nisa' ayat 58 :

"Sesungguhnya Allah menyuruh kamu menyampaikan amanat kepada yang berhak menerimanya, dan (menyuruh kamu) apabila menetapkan hukum di antara manusia supaya kamu menetapkan dengan adil. Sesungguhnya Allah memberi pengajaran yang sebaik-baiknya kepadamu. Sesungguhnya Allah adalah Maha Mendengar lagi Maha Melihat."

Dalam ayat tersebut diisyaratkan bahwa harus menyampaikan amanat atau menjaga amanat. Dalam kontek ini yang menjadi amanat adalah berupa barang bukti. Dalam Islam istilah pinjam pakai dikenal dengan pijam meminjam (al-âriyah).

Hukum asal dari pinjam meminjam adalah mubah. Tetapi permasalahnnya, pinjam meminjam dalam masalah ini mengenai barang bukti di mana barang bukti merupakan barang titipan yang harus dijaga keutuhannya, dan berfungsi sangat penting dalam proses persidangan.

\section{Pinjam Meminjam dalam Hukum Islam}

Istilah pinjam pakai pada dasarnya hanya digunakan dalam istilah hukum perdata, dalam syari'at Islam istilah pinjam pakai dikenal dengan istilah pinjam meminjam (al-âriyah). ${ }^{\text {? }}$

Menurut etimologi bahasa arab al-âriyah berarti pinjaman. ${ }^{10}$ Sedangkan menurut terminologi fiqh ada beberapa definisi al-âriyah yang dikemukakan para ulama mazhab Syafi'i di antaranya:

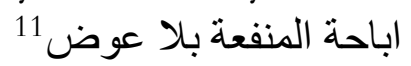

"Kebolehan memanfaatkan barang orang lain tanpa ganti rugi."

Atau kebolehan mengambil manfaat dari seseorang yang melakukan derma dengan barang yang halal untuk dimanfaatkan, serta tetap utuh zat barangnya supaya dapat dikembalikan kepada pemiliknya. ${ }^{12}$ Dari definisi ini, dapat disimpulkan bahwa barang tersebut

\footnotetext{
${ }^{8}$ Departemen Agama RI, Al-Qur'an dan Terjemahnya (Jakarta: Bumi Restu, 1976), 57.

${ }^{9}$ Helmi Karim, Fiqh Muamalah (Jakarta: Raja Grafindo Persada, 2001), 84.

${ }^{10}$ Muhammad Yunus, Kamus Arab-Indonesia (Jakarta: Hidakarya Agung, 1990), 251.

${ }^{11}$ As-Syarbaini, Al-Khatib, Mughnî AlMuḥtâj, Jilid II (Beirut: Dār al-Fikr, 1995), 264.

${ }^{12}$ Abdurrahman Al-Jaziri, Al-Fiqh 'Alâ Madhâhib Al-Arba'ah, Juz III (Beirut: Dār al Fikr, t.t.), 228.
} 
hanya boleh dimanfaatkan oleh pihak kedua, tidak boleh dimanfaatkan oleh pihak ketiga kecuali ada izin dari pihak pertama. ${ }^{13}$

Ulama Malikiyah dan Imam As-Syarakhsi mengemukakan definisinya:

$$
\text { تمليك المنفعة بغير عوض } 14
$$

"Pemilikan manfaat tanpa ganti rugi"

Menurut definisi ini, barang tersebut boleh dipinjamkan kepada pihak ketiga. Sebab ada kebebasan pemilikan manfaat dan boleh dimanfaatkan oleh orang lain (pihak ketiga). ${ }^{15}$

Menurut Ibnu Rifah yang dimaksud al-âriyah ialah memperbolehkan orang lain mengambil manfaat dari sesuatu yang bisa diambil manfaatnya dengan syarat pada saat dikembalikan kepada pemiliknya sesuatu (benda) itu eksistensisnya masih tetap. ${ }^{16}$ Sedangkan menurut al-Mawardi adalah هبة المنافع "memberikan manfaat sesuatu". ${ }^{17}$

Dari pengertian di atas dapat diketahui, meskipun penggunaan redaksinya berbeda, tetapi pokoknya sama, yaitu al-âriyah secara kebahasaan berarti pinjaman. Kata itu sudah menjadi istilah teknis dalam ilmu fiqh untuk menyebutkan aktifitas pinjam meminjam. Gambaran umum dari aktifitas al-âriyah pinjam meminjam dapat diartikan bahwa pihak pemilik memberikan barangnya untuk sementara waktu kepada pihak lain. Pihak yang menerima diperbolehkan mengambil manfaat dari barang tersebut tanpa ada satu imbalan, dan pada waktu tertentu penerima barang wajib mengembalikan barang yang tersebut dengan keadaan tetap utuh eksistensinya, karena barang pinjaman harus dikembalikan. Pelaksanaan pinjam meminjam harus dilakukan dengan sukarela. Pihak penerima harus menjaga keselamatan barang tersebut karena barang pinjaman adalah amanat yang harus dijaga.

Oleh karena itu, dapat dikemukakan bahwa pinjam meminjam merupakan perjanjian yang bertimbal balik (dua pihak) di mana pihak yang satu memberikan sesuatu barang yang tidak habis karena pemakaian, dengan ketentuan bahwa pihak yang menerima akan mengembalikan barang tersebut sebagaimana diterimanya. Misalnya si A

\footnotetext{
${ }^{13}$ M. Ali Hasan, Berbagai Transaksi Dalam Islam (Jakarta: Raja Grafindo Persada, 2003), 240.

${ }^{14}$ Ibid., 239.

${ }^{15} \mathrm{lbid}$.

${ }^{16}$ Taqiyyudin Al-Husaini, Kifâyatul Akhyâr (Beirut: Dār al-Fikr, 1994), 136.

${ }^{17}$ Ibid.
} 
meminjam sebuah motor dari si B setelah motor tersebut dipakai sesuai dengan waktu yang diperjanjikan, selanjutnya si A mengembalikan mobil tersebut kepada si B.

Bentuk dari manfaat barang pinjaman ada yang bisa dimanfaatkan secara langsung atau pun tidak langsung. Yang dapat dimanfaatkan secara langsung artinya dapat dinikmati dengan segera oleh peminjam. Contoh : si A meminjamkan bolpoin kepada si B, maka si B dapat menggunakan atau menikmati bolpoin tersebut dengan segera, dan hasilnya bisa dilihat secara langsung. Sedangkan barang yang tidak dapat dinikmati secara langsung. Misalnya si A meminjam sawah kepada si B, maka si A tidak dapat menikmati secara langsung sawah tersebut sebelum sawah tersebut ditanami oleh si A.

Hukum al-âriyah menurut Sayyid Sabiq adalah suatu yang disunnahkan. ${ }^{18}$ Sedangkan menurut al-Rauyani, 'âriyah hukumnya wajib pada saat permulaaan Islam ${ }^{19}$. Sedangkan menurut Abu Bakar Syatha', hukum al-âriyah disesuaikan dengan kondisinya (kondisional), ${ }^{20}$ ada kalanya:

a. Wajib, seperti meminjamkan tali untuk menyelamatkan orang tenggelam.

b. Haram, seperti meminjamkan pisau untuk membunuh.

c. Makruh, seperti meminjamkan budak muslim kepada orang kafir.

d. Mubah, seperti meminjamkan baju kepada orang kaya yang tidak membutuhkan.

Adapun yang menjadi dasar hukum perjanjian pinjam meminjam ini dapat disandarkan kepada ketentuan al Qur'an dan sunnah nabi Muhammad saw:

Dalam ketentuan al-Qur'an sebagai berikut:

"Tolong-menolonglah kamu dalam (mengerjakan) kebajikan dan takwa, dan jangan tolong-menolong dalam berbuat dosa dan pelanggaran. Dan bertakwalah kamu kepada Allah, Sesungguhnya Allah amat berat siksa-Nya." (QS. Al-Maidah ayat 2) ${ }^{21}$

Di dalam hadits Rasullulah saw disabdakan:

"Shafwan bin Umayah RA menceritakan, bahwa Nabi saw meminjam dari padanya beberapa baju besi pada waktu perang

\footnotetext{
${ }^{18}$ Sayyid Sabiq, Fiqh As-Sunnah, Juz 13 (Bandung: Al-Ma'arif, 1998), 38.

${ }^{19}$ Taqiyyudin Al-Husaini, Kifâyatul Akhyâr, 136.

${ }^{20}$ Abu Bakar Syatha', I'ānah al-Ṭalibîn, Juz III (Beirut: Dār al-Kitāb 'Ilmiyyah, 1995), 219.

${ }^{21}$ Departemen Agama RI, Al-Qur'an dan Terjemahnya, 107.
} 
Hunain (pada waktu itu Shafwan belum masuk Islam), maka saya tanyakan, "Apakah itu rampasan perang terhadap saya ataukah pinjaman yang dijamin?" Jawab beliau, "Pinjaman yang akan dikembalikan." 22

Berdasarkan landasan di atas, al-âriyah hukumnya mandûb, karena melakukan al-âriyah merupakan salah satu bentuk ketaatan kepada Allah SWT. ${ }^{23}$

\section{Rukun Pinjam Meminjam}

Pinjam meminjam (al-âriyah) sebagai suatu perbuatan hukum, perlu adanya unsur-unsur yang harus ada. Pinjam meminjam dianggap sah apabila sudah terpenuhi rukun dan syaratnya. Menurut jumhur ulama, rukun al-âriyah ada 4 yaitu: ${ }^{24}$

a. Orang yang meminjamkan (al-mu'îr), dalam hal ini adalah penyidik di Polsek Wonocolo Surabaya.

b. Orang yang meminjam (al-musta'îr), dalam hal ini adalah pemilik barang bukti.

c. Barang yang dipinjamkan (al-mu'âr) dalam hal ini adalah barang bukti.

d. Lafaz pinjam meminjam (sighat).

Dari kedua pendapat tersebut dapat diambil kesimpulan bahwa tiap-tiap rukun pinjam meminjam itu pada dasarnya sama, yaitu harus memenuhi beberapa unsur antara lain:

1. Pihak yang meminjamkan dan pihak yang meminjam.

2. Obyek yang dipinjamkan.

3. Sighat atau ijab qabul.

\section{Syarat Pinjam Meminjam}

Syarat merupakan unsur pelengkap dari setiap perbuatan hukum. Syarat-syarat yang harus dipenuhi dalam pinjam meminjam adalah:

1. Mu'îr (orang yang meminjamkan)

Orang yang meminjamkan (mu'îr) disyaratkan:

a. Mempunyai hak yang meminjamkan. ${ }^{25}$

\footnotetext{
${ }^{22}$ Sulaiman bin Asy'ats as-Sajistani, Sunan Abû Dâwud(Beirut: Dar al-Fikr, 1952), 313.

${ }^{23}$ M. Ali Hasan, Berbagai Transaksi Dalam Islam, 241.

${ }^{24}$ Abu Bakar Syatha', l'ânah al-Tâlibîn, Juz III, 219.

25 Taqiyyudin Al-Husaini, Kifâyatul Akhyâr, 137.
} 
Jadi, mahjûr 'alaih tidak sah meminjamkan apa yang dimilikinya. Mahjûr 'alaih adalah orang yang terlarang membelanjakan hartanya sendiri. Misalnya: Orang yang belum dewasa, idiot atau orang gila, karena mereka dianggap belum memiliki kecakapan dalam bertindak. Oleh sebab itu, baik pemilik barang maupun peminjam syaratnya harus dewasa, berakal sehat, tidak terlarang untuk membelanjakan hartanya sendiri serta harus ada maksud dan tujuan dari perbuatan yang dilakukan. Karena dalam pelaksanaan akad pinjaman ada konsekuensi yang harus disepakati, mereka harus berfikir untung rugi dari akad yang telah dilakukan. ${ }^{26}$

b. Orang yang meninjamkan harus memiliki barang yang ingin dipinjamkan. Orang yang meminjamkan dianggap tidak sah kecuali jika barang yang dipinjamkan itu benar- benar menjadi miliknya baik terhadap pokok barang itu sendiri maupun manfa'at dari barang tersebut. ${ }^{27}$

Menurut Imam Syafi'i, 'âriyah adalah akad yang jâiz ${ }^{28}$. Artinya akad al-âriyah sifatnya tidak mengikat kedua belah pihak. Pihak pemilik barang boleh membatalkan pinjaman kapan saja ia kehendaki, dan pihak peminjam juga boleh memulangkan barang pinjaman kapan saja ia mau, tanpa membedakan apakah bersifat mutlak atau terbatas.

Oleh sebab itu, orang yang meminjamkan barang disyaratkan, bahwa penarikan barang itu tidak membawa mudharat bagi peminjam, seperti tanah yang dipinjam untuk mengubur mayit. Dalam hal ini pemilik tanah tidak dapat meminta kembali tanah tersebut dengan membongkar mayat dan memindahkan ke tempat lain. Maka jalan keluar yang boleh ditempuh adalah menunggu sampai mayat itu habis di telan tanah dan barulah pemilik tanah dapat meminta tanah itu kembali. Selanjutnya dengan ditariknya kembali barang yang dipinjamkan otomatis akad al-âriyah telah berakhir.

Akad al-âriyah juga dianggap telah berakhir, ketika orang yang meminjamkan menjadi gila, hilang akalnya, atau terkena hajr

\footnotetext{
${ }^{26}$ Halmi Karim, Figh Muamalah, 40.

${ }^{27}$ Ibnu Rusyd, Bidâyatul Mujtahid, Juz III, terj. Abdurrahman, Haris Abdullah (Semarang: Asy-Syifa', t.t.), 399 .

${ }^{28} \mathrm{Ibid}, 400$.
} 
(larangan bertindak atas hartanya sendiri). Bahkan akad al-âriyah dianggap telah berakhir dengan meninggalnya orang yang meminjamkan atau orang yang meminjam. Jadi, apabila si peminjam meninggal dunia, maka ahli warisnya berkewajiban mengembalikan barang pinjaman tersebut kepada orang yang meminjamkan. Ahli waris berdosa apabila memperlambat atau menunda pengembalian barang pinjaman. ${ }^{29}$

2. Mustâîr (orang yang meminjam)

Orang yang meminjam disyaratkan harus orang yang cakap bertindak, sebab perjanjian pinjam meminjam yang dilakukan oleh orang yang tidak cakap bertindak adalah tidak sah. ${ }^{30}$

Barang pinjaman adalah amanat yang harus dijaga oleh peminjam (musta'îr) oleh sebab itu peminjam harus bertanggung jawab terhadap barang yang dipinjam. Peminjam tidak diperbolehkan meminjamkan barang pinjamannya kepada orang lain tanpa seizin pihak pemilik barang. Seorang peminjam wajib mengganti benda yang ia pinjam, jika benda itu rusak baik seluruhnya atau sebagian, baik karena ia sengaja atau tidak sengaja. ${ }^{31}$ Sebab ia hanya diperbolehkan menggunakan manfaatnya saja, bukan untuk memiliki barangnya. Akan tetapi menurut al-Malibary, musta'îr (peminjam) diperbolehkan menggunakan (meminjamkan) kepada orang lain untuk keperluan si peminjam sendiri. Dengan demikian, jika barang yang dipinjam tersebut rusak ataupun hilang, maka peminjam wajib menggantinya, baik itu kesalahan dari pihak peminjam atau sebaliknya, hal ini sesuai dengan hadits yang berbunyi:

"Samurah bin Jundub menceritakan, bahwa Rasulullah saw bersabda, "Jangan mengambil/meminjam sesuatu bertanggung jawab atasnya, sampai tangan itu membayarnya". ${ }^{32}$

Benda yang rusak yang wajib diganti adalah yang dipakai tidak sesuai dengan kesepakatan dalam akad. Jadi, jika benda yang dipinjam itu rusak, maka peminjam harus mengganti dengan benda

\footnotetext{
29 Taqiyyudin Al-Husaini, Kifâyatul Akhyâr, 141.

${ }^{30}$ Helmi Karim, Fiqh Muamalah, 40.

${ }^{31}$ Abu Bakar Syatha', l'ânah al-Ṭâlibîn, Juz III, 233.

${ }^{32}$ Ahmad bin Hanbal, Musnad Ahmad bin Hanbal(Beirut: Dār al-Fikr, t.t.), 8.
} 
yang semisal. Adapun jika benda itu tidak didapat dengan benda yang semisal, maka dalam menggantinya ada beberapa macam, ${ }^{33}$ yaitu:

1. Mengganti dengan benda yang sama nilainya.

2. Mengganti dengan benda yang lebih tinggi nilainya.

Tentang kewajiban mengganti benda yang rusak, Imam Syafi'i berpendapat bahwa 'âriyah itu harus diganti, baik itu binatang melata, budak, mutiara, dan pakaian. Jika seseorang meminjamkan sesuatu kemudian benda itu rusak, baik karena perbuatannya atau perbuatan orang lain, maka ia harus menggantinya. Akan tetapi benda itu ada kalanya harus diganti dan ada kalanya tidak harus diganti, yang harus diganti misalnya ghasab (memanfaatkan barang tanpa seijin pemiliknya) dan yang semisal, sedangkan yang tidak harus diganti adalah wadîah (titipan), karena sudah diketahui oleh pemiliknya. ${ }^{34}$ Kewajiban mengganti benda yang rusak itu tergantung dalam kesepakatan waktu akad. Jika waktu akad tidak disyaratkan mengganti, maka tidak ada kewajiban mengganti. ${ }^{35}$

3. $M u^{\prime} \hat{a} r$ (barang yang dipinjam)

Syarat dari barang yang yang dipinjamkan (mu'âr $)$ harus memenuhi persyaratan diantaranya:

a. Barang tersebut adalah barang yang bermafaat, karena apabila barangnya tidak dapat diambil manfaatnya, maka otomatis tujuan peminjaman tidak terpenuhi .

b. Barang tersebut itu bukan jenis barang yang apabila dimanfaatkan akan habis atau musnah, seperti makanan. Selain itu barang yang dipinjam harus secara langsung dapat dikuasai peminjam. ${ }^{36}$ Artinya dalam akad al-âriyah pihak peminjam harus menerima barang itu dan dapat dimanfaatkan secara langsung.

c. Bukan barang haram, barang yang dipinjamkan merupakan bukan barang haram. Misalnya apabila meminjamkan babi untuk acara ritual tertentu.

d. Manfaat barang yang dipinjam, adalah manfaat yang mubah (diperbolehkan shara). Misalnya tidak boleh meminjamkan

\footnotetext{
${ }^{33}$ Abu Ishak As-Shirazi, Al-Muhadhdhab (Beirut: Dār al-Fikr, 1994), 189.

${ }^{34}$ Al Imam Muhammad bin Idris As Syafi'i, Al-Umm (Beirut Lebanon: Dārul Kutub Al 'Alamiyyah, t.t.), 250

${ }^{35} \mathrm{lbid}$.

${ }^{36}$ Nasrun Harun, Figh Muamalah (Jakarta: Gaya Media Pratama, 2000), 240.
} 
senjata kepada musuh atau kepada penjahat, rumah untuk berjudi dan prostitusi. ${ }^{37}$

\section{Sighat (lafaz ijab qabul)}

Sighat atau lafaz ijab qabul adalah ucapan serah terima, maka disyaratkan hendaknya ucapan yang memberikan isyarat memberi izin memanfaatkan, baik ucapan itu dari peminjam ataupun dari yang meminjamkan. Ucapan dari peminjam misalnya: "Pak, saya pinjam sepeda untuk membeli pensil di toko buku". Sedangkan perkataan ucapan dari pemilik barang misalnya: "pinjamlah kambing ini dan ambillah susu dan anaknya” ${ }^{38}$

Menurut Nawawi, ucapan tersebut sah dan bahkan peminjam boleh mengambil susu dan anaknya. Apabila binatang yang dipinjamkan itu bernilai lebih seperti gemuk, kurus, maka peminjam tidak berkewajiban menanggung kekurangan (kekurusan) pada binatang itu. ${ }^{39}$ Jadi, apabila barang yang dipinjam itu mengalami penyusutan atau kemerosotan, maka pihak peminjam tidak bertanggung jawab, begitu juga sebaliknya, apabila barang tersebut menjadi bernilai tinggi maka pihak peminjam juga tidak berhak memikinya.

5. Meminjamkan pinjaman dan menyewakannya

Abu Hanifah dan Malik berpendapat bahwa peminjam boleh meminjamkan barang pinjaman kepada orang lain, sekalipun pemiliknya belum mengizinkan jika penggunaannya untuk hal-hal yang tidak berlainan dengan tujuan pemakaian peminjam.

Menurut Mazhab Hambali, manakala pinjam meminjam telah berlangsung, peminjam boleh memanfaatkannya sendiri atau siapa saja yang menggantikan statusnya, kecuali jika barang tersebut ia sewakan. Dan ia tidak boleh meminjamkannya secara sewaan, tanpa seizin pemilik. Jika ia meminjamkan tanpa izin si pemilik, kemudian barang tersebut menjadi rusak di tangan kedua, maka si pemilik berhak untuk meminta jaminan pada seorang di antara keduanya. Dan dalam keadaan seperti ini, jaminan berada dalam tanggung jawab orang (peminjam) kedua. Karena dialah yang memegang, dengan dasar barang tersebut rusak di tangannya. Karena itu

\footnotetext{
${ }^{37}$ M. Ali Hasan, Berbagai Transaksi dalam Islam, 243.

${ }^{38}$ Taqiyyudin Al-Husaini, Kifâyatul Akhyâr, 139.

${ }^{39}$ Ibid., 144.
} 
kewajiban menjamin berada padanya, seperti orang yang mengghașab terhadap orang yang dighasabnya.

6. Jaminan peminjam

Menurut Ibnu Abbas, Aisyah, Abu Hurairah, As-Syafii dan Ishak bahwa, jika barang pinjaman telah berada pada si peminjam, kemudian barang tersebut rusak, maka si peminjam berkewajiban menjaminnya, baik karena pemakaian yang berlebihan atau tidak.

Para pengikut Mazhab Hanafi dan Maliki berpendapat: "bahwa si peminjam tidak berkewajiban menjamin barang kecuali karena tindakan yang berlebih-lebihan".

Hal ini berdasarkan sabda Rasullullah saw:

"Peminjam tidak bertanggung jawab apa-apa selama ia tidak berkhianat, dan tidak pula atas orang tempat menitipkan/mempertaruhkan barang beban, selama ia tidak berkhianat atasnya." ${ }^{40}$

\section{Gambaran Umum Polsek Wonocolo Surabaya}

Kepolisian sektor Wonocolo didirikan pada tanggal 1 Juli 1986, yang berada di bawah koordinasi Kepolosian Resort Surabaya Selatan. Kepolisian sektor ini berkedudukan di jln. Margorejo Indah gang 19 No.1 Surabaya. Surabaya sendiri terbagi menjadi tiga kepolisian resort, yakni Kepolisian resort Surabaya timur, Kepolisian resort Surabaya utara dan kepolisian resort Surabaya selatan. Dan Polsek Wonocolo merupakan kepolisian yang berwenang menangani masalah yang ada di wilayah kecamatan Wonocolo.

Garis komando dari kepolisian dimulai dari;

1. Kepolisian Negara Republik Indonesia yang berkedudukan di Jakarta (ibu kota negara).

2. Kepolisian Daerah Jawa Timur yang berkedudukan di Surabaya.

3. Kepolisian wilayah yang berkedudukan di Surabaya Timur.

4. Kepolisian Resort Surabaya Selatan yang berkedudukan di Kupang Surabaya.

5. Kepolisian sektor Wonocolo yang berkedudukan di Margorejo Surabaya.

\footnotetext{
40 Ali bin Umar Abu Hasan ad-Daruqutni, Sunan Dâruquṭi, Juz III (Beirut: Dār al-Ma'rifah, 2001),
} 41. 
Di kepolisian ini dipimpin oleh seorang kepala kepolisian sektor dengan pangkat AKP Esti Setija Oetami, SH, yang merupakan salah satu Kapolsek wanita di lingkungan Surabaya selatan. Sebagai pendukung dalam kinerjanya kepolisian ini mempunyai beberapa unit divisi yaitu:

1. Tata urusan dalam

Unit ini bertugas untuk mengawasi kegiatan-kegiatan internal Polsek itu sendiri.

2. Sentra pelayanan masyarakat

Unit ini bertugas untuk melayani kebutuhan-kebutuhan masyarakat. Misalnya membuat SKCK dan surat-surat keterangan lainnya. Di samping itu unit ini menerima laporan dan pengaduan dari masyarakat mengenai persoalan-persoalan kemasyarakatan.

3. Intelejen dan komunikasi

Unit ini bertugas mengadakan pengintaian-pengantaian terhadap hal-hal yang membahayakan dan berkaitan dengan tindak pidana, serta memberikan informasi kepada masyarakat tentanga kinerja Polri.

4. Reserse dan kriminal

Unit ini menangani masalah-masalah yang berkaitan dengan tindak pidana.

5. Patroli

Unit ini bertugas melakukan pengawasan keamanan dan ketertiban di seluruh wilayah Polsek tersebut.

6. Lalu lintas

Mengatur lalu lintas di wilayah Polsek dan segala kegiatan yang berkaiatan dengan keamanan dam ketertiban lalu lintas

7. Badan bimbingan keamanan dan ketertiban masyarakat

Unit ini bertugas memberikan bimbingan kepada masyarakat dalam rangka penciptaan keamanan dan ketertiban di wilayah Polsek tersebut.

Semua unit ini mempunyai peran masing-masing, yang satu sama lain tunduk pada satu garis komando yaitu pada kepala Kepolisian Sektor. Keberadaan Polsek Wonocolo tersebut berdasarkan keputusan kaPolri no.pol : kep / 54 / 2004. 


\section{Tugas dan Wewenang Kepolisian Wonocolo Surabaya}

\section{Tugas Kepolisian}

Semua negara di dunia memiliki sebuah institusi yang berfungsi sebagai aparat keamanan yaitu kepolisian. ${ }^{41}$ Walaupun bentuk dan namanya berbeda-beda namun mempunyai tugas dan fungsi yang hampir sama, yaitu menciptakan keamanan dan ketertiban umum. Tugas itu lalu dirinci dalam tugas yang bersifat represif atau penindakan pelanggaran hukum. Begitu pula di Indonesia, terdapat lembaga atau institusi yang bernama kepolisian Negara republic Indonesia (POLRI). Polri pada hakikatnya bertugas untuk mewujudkan masyarakat yang tata-tentrem-karta-raharja.

Untuk melaksanakan tugas tersebut tidaklah ringan, karena pada dasarnya setiap manusia mempunyai keinginan untuk hidup bebas. Namun dengan adanya peraturan-peraturan yang didukung oleh Polisi, maka mau tidak mau mereka harus bertindak sesuai dengan peraturan tersebut. Perbedaan kepentingan dan persinggungan antara tugas Polri dan tindakan masyarakat sangat sering terjadi. Persinggungan yang terjadi membuat posisi Polri menjadi dilematis. Karena Polri tugasnya adalah melayani masyarakat dan melindungi masyarakat, tetapi di lain pihak tidak jarang harus memaksa seseorang untuk patuh pada hukum dan harus mengurangi kebebasan dirinya.

Pada hakikatnya, Polri harus berperan ganda dalam upaya memerangi kejahatan dia harus bertindak keras. Namun dalam membina, membimbing dan mengayomi masyarakat, dia harus berwibawa, sabar, murah senyum, sebagai sahabat-sahabat masyarakat. Polri dalam melaksanakan tugasnya tidak boleh sewenang-wenang dan semuanya diatur dalam KUHAP dan UU kepolisian sehingga segala tindakan polisi di luar jalur hukum harus ditindak tegas dan di beri sanksi yang keras. Disinilah tugas Polri harus menganut asas legalitas, dimana Polri harus mematuhi dan melaksanakan KUHAP dengan baik.

Di lain pihak, Polri harus melakukan kegiatan pencegahan atau prevensi yang dirumuskan dengan penugasan, menjaga keamanan dan memelihara ketertiban umum. Dalam hal ini berlaku asas "aportunitas". Artinya polisi boleh melakukan apa saja asal bertujuan

\footnotetext{
${ }^{41}$ Leden Marpaung, Proses Penangan Perkara Pidana, 43.
} 
mewujudkan keamanan dan ketertiban. Kata "boleh" bukan berarti melanggar hukum, tapi tindakan itu harus sesuai dengan prosedur hukum.

Sebagaimana yang diatur dalam UU kepolisian no.2 tahun 2002 tugas kepolisian meliputi:

1. Tugas pokok Kepolisian Negara Republik Indonesia adalah:

a. Memelihara keamanan dan ketertiban masyarakat;

b. Menegakkan hukum; dan

c. Memberikan perlindungan, pengayoman, dan pelayanan kepada masyarakat.

2. Untuk mendukung tugas pokok, kepolisian Negara Republik Indonesia bertugas :

a. Melaksanakan pengaturan, penjagaan, pengawalan, dan patroli terhadap kegiatan masyarakat dan pemerintah sesuai kebutuhan;

b. Menyelenggarakan segala kegiatan dalam menjamin keamanan, ketertiban, dankelancaran lalu lintas di jalan;

c. Membina masyarakat untuk meningkatkan partisipasi masyarakat, kesadaran hukum masyarakat serta ketaatan warga masyarakat terhadap hukum dan peraturan perundangundangan;

d. Turut serta dalam pembinaan hukum nasional;

e. Memelihara ketertiban dan menjamin keamanan umum;

f. Melakukan koordinasi, pengawasan, dan pembinaan teknis terhadap kepolisian khusus, penyidik pegawai negeri sipil, dan bentuk-bentuk pengamanan swakarsa;

g. Melakukan penyelidikan dan penyidikan terhadap semua tindak pidana sesuai dengan hukum acara pidana dan peraturan perundang-undangan lainnya;

h. Menyelenggarakan identifikasi kepolisian, kedokteran kepolisian, laboratorium forensik dan psikologi kepolisian untuk kepentingan tugas kepolisian;

i. Melindungi keselamatan jiwa raga, harta benda, masyarakat, dan lingkungan hidup dari gangguan ketertiban dan/atau bencana termasuk memberikan bantuan dan pertolongan dengan menjunjung tinggi hak asasi manusia; 
j. Melayani kepentingan warga masyarakat untuk sementara sebelum ditangani oleh instansi dan/atau pihak yang berwenang;

k. Memberikan pelayanan kepada masyarakat sesuai dengan kepentingannya dalam lingkup tugas kepolisian; serta

1. Melaksanakan tugas lain sesuai dengan peraturan perundangundangan. ${ }^{42}$

\section{Wewenang Kepolisian}

Dalam sistem peradilan hukum pidana, polisi mempunyai wewenang sebagai:

a. Penyelidik;

Penyelidik adalah pejabat Polisi Negara Republik Indonesia yang diberi wewenang oleh UU ini untuk melakukan penyelidikan. Sedangkan penyelidikan adalah serangkaian tindakan penyelidik untuk mencari dan menemukan suatu peristiwa yang diduga sebagai tindak pidana guna menemukan dapat atau tidaknya dilakukan penyidikan menurut cara yang dilakukan dalam UU ini.

Berdasarkan pasal 5 KUHAP, penyelidik mempunyai wewenang:

1) Menerima laporan dan pengaduan dari seseorang tentang adanya tindak pidana.

Kasus pencurian merupakan delik aduan, jadi seorang polisi akan melakukan penyelidikan lebih lanjut setelah ada laporan atau seseorang yang mengadu telah terjadi pencurian. Maka atas laporan tersebut polisi akan melakukan penyelidikan sebagai langkah awal apakah memang benar-benar telah terjadi tindak pidana pencurian atau tidak.

2) Mencari keterangan dan barang bukti

Untuk dapat memastikan apakah telah terjadi tindak pidana tersebut biasanya penyelidik di Polsek Wonocolo mencari keterangan dan barang bukti. Keterangan tesebut bisa diperoleh dari saksi-saksi yang melihat kejadian tersebut atau seseorang yang mengetahui tentang terjadinya tindak pidana pencurian tersebut. Di samping mencari keterangan,

${ }^{42}$ UU Kepolisian No.2 Th 2002. 
penyelidik mencari barang bukti, apakah itu berupa alat-alat yang digunakan oleh pelaku atau berupa hasil curian atau segala sesuatu yang berhubungan dengan tindak pidana pencurian tersebut.

3) Menyuruh berhenti seorang yang dicurigai dan menanyakan serta memeriksa tanda pengenal diri

Hal ini merupakan rangkaian tindakan untuk mencari keterangan dan untuk mengetahui apakah ada keterlibatan dari seseorang yang dicurigai tersebut.

4) Mengadakan tindakan lain yang menurut hukum yang bertanggung jawab

Dan atas perintah penyidik dapat melakukan tindakan berupa:

1) Penangkapan, larangan meninggalkan tempat, penggeledahan dan penyitaan;

2) Pemeriksaan dan penyitaan surat;

3) Mengambil sidik jari dan memotret seorang

4) Membawa dan menghadapkan seorang ke penyidik.

b. Penyidik;

Penyidik adalah pejabat polisi negara republik Indonesia atau pegawai negeri sipil tertentu yang diberi wewenang khusus oleh UU untuk melakukan penyidikan. Tapi untuk perkara pidana pencurian yang bertindak sebagai penyidik hanya penyidik dari Polri. Penyidikan berarti serangkaian tindakan penyidik alam hal dan menurut cara yang diatur dalam UU ini untuk mencari dan mengumpulkan bukti, yang dengan bukti itu membuat terang tentang tentang tindak pidana yang terjadi dan guna menemukan tersangkanya. Di Polsek Wonocolo Surabaya, yang bertugas sebagai penyidik berasal dari unit reserse dan kriminal.

Berdasarkan pasal 7 KUHAP penyidik mempunyai wewenang sebagai berikut:

1. Menerima laporan atau pengaduan dari seseorang tentang adanya tindak pidana.

2. Melakukan tindakan pidana pada saat di tempat kejadian

3. Menyuruh berhenti seorang tersangka dan memeriksa tanda pengenal diri tersangka 
4. Melakukan penangkapan, penahanan, penggeledahan dan penyitaan

5. Melakukan pemeriksaan dan penyitaan surat

6. Mengambil sidik jari dan memotret seorang

7. Mengambil orang untuk didengar dan diperiksa sebagai tersangka atau saksi

8. Mendatangkan orang ahli yang diperlukan dalam hubungannya dengan pemeriksaan perkara

9. Mengadakan penghentian penyidikan

10.Mengadakan tindakan lain menurut hukum yang bertanggung jawab.

\section{Barang Bukti di Polsek Wonocolo Surabaya}

a. Pengertian barang bukti

Barang bukti adalah barang-barang, baik yang berwujud atau tidak berwujud, bergerak atau tidak bergerak, yang dapat dijadikan bukti di pengadilan. ${ }^{43}$ Barang bukti dalam perkara pidana merupakan faktor yang harus diperhatikan baik oleh Penyidik, Penuntut Umum atau Hakim. Oleh karena itu, sudah seharusnya barang bukti tersebut diusahakan oleh penyidik agar proses penyelesaian perkara pidana dapat berjalan dengan lancar. ${ }^{44}$

Yang dimaksud benda berwujud (lichamelejke zaken) yaitu benda yang dapat ditangkap dengan panca indra. Sedangkan benda yang tak berwujud (onlichamelejke zaken) yakni hak-hak subyektif. Jadi sesuatu hak dapat merupakan obyek dari hak yang lain misalnya; hak manfaat atas tagihan utang yang memberikan bunga atau hak gadai atau tagihan utang. ${ }^{45}$

Benda bergerak terdiri:

1. Benda bergerak karena sifatnya menurut pasal 509 KUH Perdata ialah benda yang dapat dipindahkan misalnya: meja, atau dapat dipindakan dengan sendirinya, misalnya: ternak.

2. Benda bergerak karena ketentuan Undang-undang menurut 511 KUH Perdata ialah hak-hak atas benda yang bergerak, misalnya:

${ }^{43}$ Djoko Prakoso, Alat Bukti dan Kekuatan Pembuktian di dalam Proses Pidana, 146.

${ }^{44}$ Ibid

${ }^{45}$ Apeldoorn, Pengantar Ilmu Hukum, 172. 
hak memungut hasil atas benda bergerak, hak pemakaian atas benda bergerak, saham-saham daripada NV dan lain-lain.

Sedangkan benda tak bergerak ialah benda yang tidak dapat dipindahkan, misalnya: tanah. ${ }^{46}$

b. Jenis-jenis barang bukti

Barang atau benda yang disita pada dasarnya adalah barang yang dapat dijadikan barang bukti. ${ }^{47}$ Dengan kata lain jenis-jenis barang bukti adalah barang yang dapat disita.

Barang-barang yang dapat disita adalah:

a. Barang-barang yang menjadi sasaran perbuatan yang melanggar hukum pidana (corpea delicti).

b. Barang-barang yang di dapat dari perbuatan yang melanggar hukum pidana.

c. Barang-barang yang dipakai sebagai alat untuk melakukan perbuatan yang melanggar hukum pidana (instrumenta delicti).

d. Barang-barang yang pada umumnya dapat menjadi barang bukti kearah memberatkan atau menguntungkan kesalahan terdakwa. ${ }^{48}$

Dalam KUHAP pasal 39 ayat 1, dinyatakan bahwa bendabenda yang dapat dikenakan penyitaan adalah:

a. Benda atau tagihan tersangka atau terdakwa yang seluruh atau sebagian diduga diperoleh dari tindak pidana atau sebagai hasil dari tindak pidana.

b. Benda-benda yang telah dipergunakan secara langsung untuk melakukan tindak pidana atau untuk mempersiapkannya.

c. Benda yang dipergunakan untuk menghalang-halangi penyidikan tindak pidana

d. Benda yang khusus dibuat atau dipergunakan melakukan tindak pidana

e. Benda lain yang mempunyai hubungan langsung dengan tindak pidana yang dilakukannya.

Dalam menjalankan tugasnya Polri dituntut untuk bersikap secara profesional dalam menangani kejahatan yang terjadi di masyarakat.

\footnotetext{
${ }^{46}$ Sri Soedewi, Hukum Perdata dan Hukum Benda, 20-21.

47 Djoko Prakoso, Alat Bukti dan Kekuatan Pembuktian di dalam Proses Pidana, 156.

${ }^{48}$ Wirjono Prodjodikoro, Hukum Acara Pidana di Indonesia, 58.
} 
Tingkat kejahatan antar tiap daerah berbeda, apalagi di kota besar seperti kota Surabaya tingkat kejahatan yang ditangani juga besar, keadaan seperti ini membuat barang bukti yang ditemukan juga semakin banyak. Berdasarkan data yang dihimpun oleh penulis, jumlah barang bukti dari hasil tindak pidana pencurian yang masuk dalam kurun waktu antara bulan Januari sampai desember 2008 ada sekitar 126 barang bukti hasil tindak pidana pencurian di Polsek Wonocolo dengan perincian sebagai berikut: ${ }^{49}$

\begin{tabular}{|c|l|c|}
\hline No. & $\begin{array}{c}\text { Jenis barang bukti hasil tindak } \\
\text { pidana pencurian }\end{array}$ & Jumlah \\
\hline 1. & Sepeda motor & 3 \\
\hline 2. & Televisi & 20 \\
\hline 3. & Sepeda & 5 \\
\hline 4. & Computer & 25 \\
\hline 5. & Uang & 3.575 .000 \\
\hline 6. & Laptop & 18 \\
\hline 7. & Perhiasan & 25 \\
\hline 8 & Handpone & 30 \\
\hline \multicolumn{2}{|c|}{ Jumlah } & 126 \\
\hline
\end{tabular}

Dari tabel diatas jelas bahwa yang paling banyak barang bukti hasil tindak pidana pencurian yang ditemukan adalah handpone.

\section{Kewajiban Polsek Wonocolo Surabaya terhadap Barang Bukti}

Dalam KUHAP telah diatur pejabat-pejabat mana saja yang diperbolehkan melaksanakan tugas mengamankan barang-barang yang dijadikan bukti dalam suatu perkara pidana. Adapun pengertian "mengamankan" disini dimaksudkan penulis adalah wewenang untuk mencari, menerima dan menyimpan hingga barang bukti tersebut sampai pada saatnya diajukan ke muka persidangan. Pengamanan yang baik seperti yang dimaksud sudah barang tentu akan menambah dan mempercepat proses pentelesaian suatu perkara pidana yang ada.

Jika dilihat dalam KUHAP "mengamankan" barang bukti merupakan wewenang dari penyidik. Dalam pasal 6 ayat 1 ditentukan yang termasuk penyidik adalah:

a. Pejabat Polisi Negara Republik Indonesia.

\footnotetext{
${ }^{49}$ Data Statistik Polsek Wonocolo Tahun 2008
} 
b. Pejabat Pegawai Negeri Sipil tertentu yang diberi wewenang khusus oleh undang-undang.

Mereka inilah yang mempunyai wewenang mengamankan barang bukti. Sedangkan tempat penyimpanan barang bukti menurut KUHAP sudah ditentukan pula yaitu "dalam rumah penyimpanan benda sitaan Negara". Namun selama belum ada rumah penyimpanan benda sitaan Negara di tempat yang bersangkutan, penyimpanan benda sitaan tersebut dapat dilakukan di kantor Kepolisian Negara Republik Indonesia, di kantor Kejaksaan Negeri, di kantor Pengadilan Negeri, di gedung bank pemerintah dan dalam keadaan terpaksa di tempat penympanan lain atau tetap di tempat semula benda itu disita. ${ }^{50}$

\section{Prosedur Pinjam Pakai Barang Bukti Hasil Tindak Pidana Pencurian di Polsek Wonocolo.}

Ada beberapa tahapan dalam proses pinjam pakai barang bukti hasil tindak pidana pencurian di Polsek Wonocolo Surabaya, dari proses permohonan pinjam pakai hingga persetujuan pemakaian barang bukti oleh peminjam. Persetujuan permohonan pinjam pakai pada dasarnya dipersulit, sebab penyidik sangat selektif terhadap setiap pemohon yang akan mengajukan pinjam pakai barang bukti. Terbukti selama tahun 2008 Bripka Adi sebagai penyidik hanya menerima permohonan pengajuan pinjam pakai hanya seorang saja. Dasar pertimbangan penyidik dalam penyeleksian permohonan pengajuan pinjam pakai barang bukti adalah:

1. Barang bukti keberadaannya sangat penting, fungsinya untuk diperlihatkan kepada terdakwa atau saksi di persidangan guna mempertebal keyakinan hakim dalam menentukan kesalahan terdakwa.

2. Adanya kekhawatiran pihak penyidik apabila sewaktu-waktu barang bukti diperlukan, barang bukti tersebut tidak ada.

Prosedur dalam proses pinjam pakai barang bukti hasil tindak pidana pencurian di Polsek Wonocolo Surabaya terdapat beberapa tahapan sebagai berikut:

a. Membuat surat permohonan

Proses pemberian izin pinjam pakai barang bukti hasil tindak pidana pencurian dimulai dengan permohonan oleh calon peminjam

${ }^{50}$ Pejelasan Pasal 44 KUHAP 
pinjam pakai barang bukti, dengan membuat surat permohonan yang ditujukan pada kepala Polsek setempat.

b. Melengkapi syarat-syarat permohonan

Setelah pemohon pinjam pakai mengajukan surat permohonan pada kepala Polsek dengan pertimbangan-pertimbangan dari penyidik, maka pemohon harus memenuhi syarat-syarat yang diperlukan. Syarat permohonan cukup mudah yaitu hanya dengan membawa bukti kepemilikan barang yang akan dipinjam pakai. Pemohon wajib membawa bukti kepemilkan barang yang akan dipinjam, hal ini penting untuk mengetahui apakah benar-benar barang yang akan dipinjam pakai adalah miliknya atau bukan. Misalnya: apabila pemohon akan meminjam barang bukti berupa sepeda motor maka ia harus membawa buku Bukti Pemilikan Kendaraan Bermotor (BPKB). BPKB tersebut sesuai dengan nama pemohon pinjam pakai. Namun, apabila masih atas nama orang lain (kendaraan bekas orang lain) dan belum dibalik nama, maka dalam permohonan tersebut dilampiri dengan bukti-bukti kuitansi pembelian.

Syarat-syarat tersebut menjadi acuan bagi penyidik dalam menyetujui permohonan pinjam pakai barang bukti karena mengingat barang bukti berfungsi sebagai sarana pendukung yang memperkuat keyakinan hakim dalam memutus kesalahan dan menjatuhkan pidana terhadap terdakwa (pasal 183 KUHAP).

c. Penyidik mempertimbangkan permohonan pemohon

Dalam menanggapi surat permohonan pemohon, penyidik tidak langsung menyetujui permohonan pinjam pakai. Di sini penyidik akan mempertimbangkan apakah si pemohon bisa merawat barang bukti tersebut atau tidak, apakah pemilik bisa dipercaya apabila sewaktu-waktu barang bukti tersebut dibutuhkan dapat menghadirkan dalam proses persidangan.

d. Persetujuan Kapolsek

Kapolsek akan menyetujui permohonan pinjam pakai barang bukti atas dasar persetujuan dari penyidik, jika penyidik menyetujui permohonan maka Kapolsek akan menyetujui pula. Karena, pada hakekatnya barang bukti yang telah disita adalah tanggung jawab penyidik, Kapolsek hanya menyetujui dan melegalkan permohonan tersebut. 


\section{Dasar Hukum Penerapan Pinjam Pakai Barang Bukti di Polsek Wonocolo Surabaya}

Di Polsek Wonocolo Surabaya, praktek pinjam pakai barang bukti tergolong langka, hal ini bisa dilihat dari permohonan yang ada selama tahun 2008 yang ditangani oleh Bripka Supriyadi hanya satu permohonan. Hal ini disebabkan karena permohonan pinjam pakai pada penyidik yang menangani kasus tersebut tidak mudah. Kekhawatiran penyidik jika sewaktu-waktu barang tersebut dibutuhkan dalam proses persidangan tidak ada di tempat merupakan dasar pertimbangan penyidik yang utama. Karena barang bukti yang telah disita adalah menjadi tanggung jawab penyidik, sehingga barang bukti tersebut harus tetap dijaga dan dirawat sebaik-baiknya agar tidak berubah dari pertama kali barang tersebut ditemukan. ${ }^{51}$

Hal itu sesuai dengan KUHAP pasal 44 ayat 2 yang berbunyi:

\section{Pasal 44}

(2) Penyimpanan benda sitaan dilaksanakan dengan sebaik-baiknya dan tanggung jawab atasnya ada pada pejabat yang berwenang sesuai dengan tingkat pemeriksaan dalam proses peradilan dan benda tersebut dilarang untuk dipergunakan oleh siapapun juga" ${ }^{2}$

Namun adanya praktek pinjam pakai barang bukti bukan berarti tidak diperbolehkan, pemberian izin pinjam pakai didasarkan atas kebijaksanaan penyidik semata demi kepentingan perikemanusiaan.

Dasar pertimbangan-pertimbangan barang tersebut dipinjamkan kepada pemiliknya antara lain adalah:

a) Barang tersebut karena sifat atau ujudnya tidak akan mengganggu kepentingan persidangan.

b) Kepentingan hak-hak dasar manusia dari peminjam/ pemilik barang tersebut, misalnya untuk kebutuhan yang sangat mendesak.

c) Peminjam atau pemilik barang tersebut membuat pernyataan atau perjanjian diatas segel menyatakan sanggup bahwa barang tersebut sewaktu-waktu dibutuhkan untuk kepentingan persidangan dapat segera mengembalikan dalam keadaan seperti semula..$^{53}$

\footnotetext{
${ }^{51}$ Bripka Supriyadi (Penyidik di Polsek Wonocolo Surabaya), Wawancara.

${ }^{52}$ KUHAP, 26.

${ }^{53}$ Iptu Simun Irianto (WaKapolsekta Polsek Wonocolo Surabaya), Wawancara.
} 
Selain itu, menurut Aiptu Simun dasar pertimbangan penyidik dalam praktek pinjam pakai barang bukti adalah KUHAP pasal 45 ayat 1 :

Dalam hal benda sitaan terdiri atas benda yang dapat lekas rusak atau yang membahayakan, sehingga tidak mungkin untuk disimpan sampai putusan pengadilan terhadap perkara-perkara yang bersangkutan memperoleh kekuatan hukum tetap atau jika biaya penyimpanan benda tersebut akan menjadi terlalu tinggi, sejauh mungkin dengan persetujuan tersangka atau kuasanya akan diambil tindakan sebagai berikut:

a. Apabila perkara masih ada di tangan penyidik atau penuntut umum, benda diamankan oleh penyidik atau penuntut umum, dengan disaksikan oleh tersangka atau kuasanya.

b. Apabila perkara sudah ada di tangan pengadilan, maka benda tersebut dapat diamankan atau dijual lelang oleh penuntut umum atas izin hakim yang menyidangkan perkaranya dan disaksikan oleh terdakwa atau kuasanya. ${ }^{54}$

Menurut beliau, dalam pasal tersebut jelas bahwa barang sitaan/barang bukti tersebut lekas rusak atau memerlukan biaya penyimpanan (perawatan) tinggi, maka barang bukti tersebut dapat "diamankan" oleh penyidik atau oleh penuntut umum. Kata "diamankan" disini mempunyai arti barang tersebut boleh dipinjam pakai, karena barang bukti tersebut sudah menjadi tanggung jawab penyidik.

Analisis Hukum Islam terhadap Prosedur dan Dasar Hukum Pinjam Pakai Barang Bukti Hasil Tindak Pidana Pencurian di Polsek Wonocolo Surabaya

Tahapan-tahapan dalam prosedur pinjam pakai barang bukti pencurian di kepolisian pada dasarnya sama saja, tidak ada perbedaan antara kepolisian yang satu dengan yang lain. Dalam Islam aturan yang sistematis sangat dihargai, terlebih dalam transaksi atau akad yang masih

\footnotetext{
${ }^{54}$ KUHAP, 26.
} 
dalam proses penyelesaian. Dalam hal ini Allah berfirman dalam surat Al-Baqarah ayat 282:

"Hai orang-orang yang beriman, apabila kamu bermu'amalah tidak secara tunai untuk waktu yang ditentukan, hendaklah kamu menuliskannya. Dan hendaklah seorang penulis di antara kamu menuliskannya dengan benar."

Dengan demikian, dapat diambil kesimpulan bahwa Islam sangat menganjurkan umatnya untuk selalu amanat dan adil dengan segala perjanjian yang dibuat demi kemaslahatan bersama. Sebagaimana yang telah dijelaskan dalam bab sebelumnya bahwa rukun dan syarat sah pinjam meminjam (al-'âriyah) adalah:

a. Orang yang meminjamkan (al-mu'îr

b. Orang yang meminjam (al-musta'îr

c. Barang yang dipinjamkan (al-mu'îr)

d. Lafadz pinjam meminjam (sighat)

Jika dilihat dari tahapan tahapan yang ada, dalam pelaksanaan pinjam pakai barang bukti di Polsek Wonocolo Surabaya semua rukun dan syarat telah terpenuhi sehingga prosedur tersebut tidaklah bertentangan dengan konsep yang telah tertata dalam Islam.

Dalam permohonan pinjam pakai di Polsek Wonocolo Surabaya memang tidak ada uang pembayaran kompensasi, sehingga pemohon pinjam pakai tidak perlu mengeluarkan uang untuk meminjam barang telah menjadi benda sitaan kepada Polsek setempat. Dalam Islam pada prinsipnya suatu perjanian pinjam meminjam memang tidak dibenarkan memungut uang, hal ini sejalan dengan prinsip pinjam meminjam yaitu adanya saling tolong menolong.

Prosedur yang telah dibuat oleh kepolisian seperti yang telah dijelaskan di atas. Pada dasarnya semata-mata merupakan seperangkat tata administrasi untuk menjaga atau memelihara barang bukti pencurian. Upaya yang demikian, merupakan kebebasan pemerintah yang dalam hal ini adalah pihak kejaksaan atau kepolisian dalam menentukan tata laksananya atau prosedurnya. Islam tidak melarang, bahkan menyerahkan sepenuhnya kepada manusia untuk mengatur atau mengurus masalah-masalah keduniaan, karena manusia sendiri dipandang mampu mengurusnya. 


\section{Analisis Hukum Islam terhadap Dasar Hukum Pinjam Pakai Barang Bukti Hasil Tindak Pidana Pencurian di Polsek Wonocolo Surabaya}

Barang bukti adalah barang-barang, baik yang berwujud atau tidak berwujud, bergerak atau tidak bergerak yang dapat dijadikan bukti di pengadilan. ${ }^{55}$ Barang bukti dalam perkara pidana merupakan faktor yang harus diperhatikan baik oleh Penyidik, Penuntut Umum atau Hakim. Oleh karena itu, sudah seharusnya barang bukti tersebut diusahakan oleh penyidik, karena barang bukti berkaitan dengan pembuktian dalam proses persidangan dan agar proses penyelesaian perkara pidana dapat berjalan dengan lancar. ${ }^{56}$

Alat-alat bukti yang terpokok yang diperlukan dalam tindak pidana pencurian yaitu:
a. Iqrâr (pengakuan)
b. Shahâdah (persaksian)
c. Yamîn (sumpah)
d. Qarînah dan bukti-bukti yang lain yang dapat dipergunakan. ${ }^{57}$

Barang bukti bisa dimasukkan dalam alat bukti yang berupa qarînah dan alat bukti yang lain, sebagai contoh dalam kisah Nabi Yusuf dalam al-Qur'an surat Yusuf 26 :

"Dan seorang saksi dari keluarga wanita itu memberikan kesaksiannya: "Jika baju gamisnya koyak di muka, maka wanita itu benar dan Yusuf termasuk orang-orang yang dusta." ${ }^{58}$

Qarînah dari kasus dalam ayat di atas adalah baju gamis yang koyak. Baju gamis tersebut bisa dijadikan suatu barang bukti yang selanjutnya akan dijadikan dasar penuntutan dan akan diajukan di muka sidang pengadilan untuk mendapatkan keterangan yang sebenarbenarnya dari terdakwa atau saksi.

Barang yang dijadikan sebagai bukti di pengadilan, wajib disimpan dan dijaga sebaik-baiknya, karena mengingat fungsi barang bukti ini sangat penting sebagai hujjah di persidangan nanti. Hal ini sesuai dengan al-Qur'an Surat an-Nisa' ayat 58 :

"Sesungguhnya Allah menyuruh kamu menyampaikan amanat kepada yang berhak menerimanya, dan (menyuruh kamu) apabila menetapkan hukum di antara manusia supaya kamu menetapkan

\footnotetext{
${ }^{55}$ Djoko Prakoso, Alat Bukti Dan Kekuatan Pembuktian di dalam Proses Pidana, 146.

56 Ibid.

${ }^{57}$ A. Djazuli, Fiqh Jinayah (Jakarta: Raja Grafindo Persada, 1997), 80.

${ }^{58}$ Departemen Agama RI, Al Qur'an dan Terjemahnya, 239.
} 
dengan adil. Sesungguhnya Allah memberi pengajaran yang sebaik-baiknya kepadamu. Sesungguhnya Allah adalah Maha mendengar lagi Maha Melihat."

Dalam ayat tersebut diisyaratkan bahwa harus menyampaikan amanat atau menjaga amanat. Dalam hal ini yang menjadi amanat adalah berupa barang bukti. Barang bukti tersebut harus dijaga sebaik-baiknya agar pada waktu dibutuhkan dalam proses persidangan barang tersebut tidak berubah.

Orang yang memiliki wewenang untuk mencari dan menyita barang bukti adalah penyidik. Pengertian penyidik menurut KUHAP pasal 1 yaitu penyidik adalah pejabat polisi Negara Republik Indonesia atau pegawai negeri sipil tertentu yang diberi wewenang khusus oleh UU untuk melakukan penyidikan. Salah satu tugas dari penyidik adalah melakukan penyitaan terhadap barang bukti yang telah ditemukan.

Barang bukti akan disita sampai proses persidangan selesai, dan biasanya memerlukan waktu yang relatif lama, tetapi jika orang yang kehilangan membutuhkan dengan sangat untuk keperluan sehari-hari misalnya sepeda motor untuk bekerja sehari-hari, maka di sini kepolisian memberi ijin untuk membuat permohonan pinjam pakai barang bukti kepada penyidik yang menangani kasus tersebut. Kemudian Penyidik akan mempertimbangkan alasan-alasan dari pemohon.

Dalam KUHAP pasal 45 yang berbunyi:

(1) Dalam hal benda sitaan terdiri atas benda yang dapat lekas rusak atau yang membahayakan, sehingga tidak mungkin untuk disimpan sampai putusan pengadilan terhadap perkara-perkara yang bersangkutan memperoleh kekuatan hukum tetap atau jika biaya penyimpanan benda tersebut akan menjadi terlalu tinggi, sejauh mungkin dengan persetujuan tersangka atau kuasanya akan diambil tindakan sebagai berikut:

a. Apabila perkara masih ada di tangan penyidik atau penuntut umum, benda diamankan oleh penyidik atau penuntut umum, dengan disaksikan oleh tersangka atau kuasanya.

c. Apabila perkara sudah ada di tangan pengadilan, maka benda tersebut dapat diamankan atau dijual lelang oleh penuntut umum atas izin hakim yang 
menyidangkan perkaranya dan disaksikan oleh terdakwa atau kuasanya.

Pasal tersebut juga digunakan dasar dari penyidik untuk melakukan pinjam pakai. Dasar pertimbangan-pertimbangan barang bukti tersebut dipinjamkan kepada pemiliknya antara lain adalah:

1. Barang tersebut karena sifat atau ujudnya tidak akan mengganggu kepentingan persidangan

2. Kepentingan hak-hak dasar manusia dari peminjam/ pemilik barang tersebut, misal untuk kebutuhan yang sangat mendesak

3. Peminjam atau pemilik barang tersebut membuat pernyataan atau perjanjian diatas segel menyatakan sanggup bahwa barang tersebut sewaktu-waktu dibutuhkan untuk kepentingan persidangan dapat segera mengembalikan dalam keadaan baik seperti semula.

Hal ini sejalah dengan ajaran Islam. Dalam hukum Islam diatur dalam masalah pinjam meminjam yang intinya adalah saling tolong menolong. Sebagaimana yang telah dijelaskan, bahwa dasar pertimbangan penyidik dalam menyetujui permohonan pinjam pakai barang bukti antara lain adalah faktor kemanusiaan dan agar barang bukti tetap terawat dan terjaga sehingga dalam proses persidangan barang tersebut diharapkan masih dalam keadaan tetap.

Dasar penyidik tersebut tidak bertentangan dengan metode mașlahah mursalah yakni sesuatu yang baik menurut akal dengan pertimbangan dapat mewujudkan kebaikan atau menghindarkan keburukan bagi manusia. Selain itu dasar tersebut dibenarkan oleh Islam berdasarkan kaidah ușul fiqh:

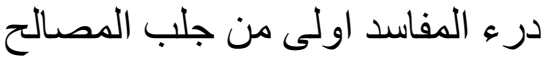

"Menolak kerusakan lebih diutamakan daripada menarik maslahah."

Menurut Abu Bakar Syatha' hukum al-'âriyah disesuaikan dengan kondisinya (kondisional), ${ }^{60}$ ada kalanya:

1. Wajib, seperti meminjamkan tali untuk menyelamatkan orang tenggelam.

2. Haram, seperti meminjamkan pisau untuk membunuh.

3. Makruh, seperti meminjamkan budak muslim kepada orang kafir.

${ }_{59}$ Muslih Usman, Kaidah-Kaidah Ushuliyah dan Fiqhiyah (Jakarta: Raja Grafindo Persada, 1997), 90.

${ }^{60}$ Abu Bakar Syatha', l'ânah al-Ṭâlibîn, Juz III, 219. 
4. Mubah, seperti meminjamkan baju kepada orang kaya yang tidak membutuhkan.

Jika dilihat dari alasan peminjam yang sangat membutuhkan barang tersebut untuk keperluan sehari-hari, maka pinjam pakai barang bukti adalah boleh dilakukan bahkan menjadi wajib jika benar-benar membutuhkannya dan yang meminjam adalah pemiliknya sendiri sehingga pemilik pasti akan menjaga barang tersebut dengan sebaikbaiknya.

Barang bukti mempunyai fungsi yang sangat penting guna mempercepat proses persidangan yaitu menambah keyakinan hakim. Sehingga sudah seharusnya barang bukti tersebut diusahakan oleh penyidik, karena barang bukti berkaitan dengan pembuktian dalam proses persidangan dan agar proses penyelesaian perkara pidana dapat berjalan dengan lancar. Tetapi dalam kenyataannya barang bukti yang keberadaannya itu sangat urgen dapat dipinjam pakai. Jika kita melihat pada pertimbangan-pertimbangan yang kemukakan oleh penyidik bahwa pemilik bisa melakukan pinjam pakai dengan alasan:

1) Barang tersebut karena sifat atau wujudnya tidak akan mengganggu kepentingan persidangan.

2) Kepentingan hak-hak dasar manusia dari peminjam/pemilik barang tersebut, misal untuk kebutuhan yang sangat mendesak.

3) Peminjam atau pemilik barang tersebut membuat pernyataan atau perjanjian diatas segel menyatakan sanggup bahwa barang tersebut sewaktu-waktu dibutuhkan untuk kepentingan persidangan dapat segera mengembalikan dalam keadaan baik seperti semula.

Dalam Islam pinjam meminjam hukum asalnya adalah mubah dan bisa berubah menjadi wajib, sesuai dengan kondisinya. Jika melihat dari alasan pemohon pinjam pakai yang ia sangat membutuhkan barang tersebut untuk kebutuhannya sehari-hari maka disini hukum dari pinjam meminjam menjadi wajib.

Dalam konsep kepemilikan dalam Islam, kepemilikan dibagi menjadi dua:

1. Milk tâm yaitu kepemilikan yang meliputi benda dan manfaatnya sekaligus. Artinya bentuk benda dan kegunannya dapat dikuasai.

2. Milk nâqișah yaitu suatu kepemilikan dimana seseorang hanya memiliki salah satu dari benda tersebut. Memiliki benda tanpa 
memiliki manfaatnya atau memiliki manfaatnya saja tanpa memiliki bendanya. ${ }^{61}$

Dalam kaitannya dengan kasus pinjam pakai di polsek Wonocolo Surabaya yang hakikatnya pemilik adalah peminjam, bisa dideskripsikan bahwa, pada mulanya peminjam barang bukti adalah pemilik sah barangnya, tetapi karena barang tersebut statusnya telah menjadi barang bukti karena tindak pidana pencurian, maka barang bukti tersebut beralih penguasaannya kepada pemerintah (penyidik polsek wonocolo surabaya). Di sini penyidik yang akan bertanggung jawab terhadap barang bukti tersebut. Status barang bukti yang berada di tangan penyidik (pemberi pinjaman) merupakan hak milik nâqișah di mana dia menguasai benda tetapi tidak bisa memanfaatkannya. Sedangkan peminjam (pemilik barang) memiliki hak milik manfaat sementara yaitu penguasaan barang terhadap kegunaannya saja untuk sementara, sebelum putusan pengadilan diputuskan. Sehingga walaupun keberadaan barang bukti adalah sangat penting tetapi jika kebutuhan menusia lebih penting, maka pinjam pakai barang bukti boleh dilakukan.

\section{Simpulan}

Prosedur pinjam pakai barang bukti hasil tindak pidana pencurian di Polsek Kecamatan Wonocolo Kota Surabaya terdapat beberapa tahapan, yaitu membuat surat permohonan, melengkapi syarat-syarat permohonan, penyidik mempertimbangkan permohonan pemohon, dan persetujuan Kapolsek. Pinjam pakai barang bukti hasil tindak pidana pencurian di Polsek Kecamatan Wonocolo Kota Surabaya adalah pertimbangan-pertimbangan penyidik sendiri, dasar pertimbanganpertimbangan barang tersebut dipinjamkan kepada pemiliknya, yaitu barang bukti tersebut digunakan diluar waktu kepentingan persidangan, pemilik sangat membutuhkan, ada surat pernyataan yang menyatakan bahwa apabila sewaktu-waktu barang tersebut dibutuhkan untuk kepentingan persidangan dapat segera mengembalikan dalam keadaan seperti semula.

Pandangan hukum Islam terhadap pinjam pakai barang bukti hasil tindak pidana pencurian di Polsek Kecamatan Wonocolo Kota Surabaya adalah boleh atau mubah bahkan bisa berubah menjadi wajib, sesuai degan kondisinya. Jika melihat dari alasan pemohon pinjam pakai

\footnotetext{
${ }^{61}$ http://74.125.153.132.dimel2002. multiply.com/journal/item/llkedudukan hak milik dalam islam
} 
yang ia sangat membutuhkan barang tersebut untuk kebutuhannya sehari-hari maka disini hukum dari pinjam meminjam menjadi wajib. Walaupun keberadaan barang bukti adalah sangat penting tetapi jika kebutuhan menusia lebih penting maka pinjam pakai barang bukti boleh dilakukan.

\section{Daftar Rujukan}

-), Ibnu Hạ̣r. Bulûghul Marâm. Terj. Hasan. Jakarta: Rineka Cipta, 1992.

Husaini (al-), Taqiyyudin. Kifâyatul Akhyâr. Beirut: Dâr al-Fikr, 1994. Jauziyah (al-), Ibnu Qayyim. Hukum Acara Peradilan Islam, terj. Adnan Qahar dan Anshoruddin. Yogyakarta: Pustaka Pelajar, 2006.

Jaziri (al-), Abdurrahman. Al-Fiqh 'Alâ Madhâhib Al-Arba’ah. Juz III. Beirut: Dâr al Fikr, t.t.

Sajistani (as-), Sulaiman bin Asy'ats. Sunan Abû Dâwud. Beirut: Dâr alFikr, 1952.

Shiddieqy (as-), Hasbi. Peradilan dan Hukum Acara dalam Islam. Semarang: Pustaka Risky Putra, 1997.

Suyuti (As-), Abdul Rahman. Jâmi’ Șaghîr. Indonesia: Dâr al-Ihyya' alKitâb al-'Arabiyyah, t.t.

Syafi'i (as-), Al Imam Muhammad bin Idris. Al-Umm. Beirut Lebanon: Dārul Kutub Al 'Alamiyyah, t.t.

Syarbaini (as-), Khatib. Mughnî al-Muhtâj. Jilid II. Beirut: Dâr al-Fikr, 1995.

Syirazi (as), Abu Ishak. Al-Muhadhdhab. Beirut: Dârul Fikr, 1994.

Daruqutni (ad-), Ali bin Umar Abu Hasan. Sunan Dâruqutni. Juz III. Beirut: Dâr al-Ma'rifah, 2001.

Departemen Agama RI. Al-Qur'an dan Terjemahnya. Jakarta: Bumi Restu, 1976.

Djazuli, A. Fiqh Jinayah. Jakarta: Raja Grafindo Persada, 1997.

Hanbal, Ahmad bin. Musnad Ahmad bin Hanbal. Beirut: Dâr al-Fikr, t.t.

Hamzah, Andi. Hukum Acara Pidana Indonesia. Jakarta: Sinar Grafika, 1993.

Harun, Nasrun. Fiqh Muamalah. Jakarta: Gaya Media Pratama, 2000. 
Hasan, Ali bin Umar Abu. Sunan Dâruquṭni. Beirut: Dârul Ma'rifah, 1966.

Hasan, M. Ali. Berbagai Transaksi dalam Islam. Jakarta: Raja Grafindo Persada, 2003.

Hendi, Suhendi. Fiqh Muamalah. Jakarta: Raja Grafindo Persada, 2002. http//www.sinarharapan.co.id

http://74.125.153.132.dimel2002.multiply.com/journal/item/IIkeduduk an hak milik dalam islam

Karim, Helmi. Fiqh Muamalah. Jakarta: Raja Grafindo Persada, 2001.

Kitab Undang-Undang Hukum Acara Pidana (KUHAP). Surabaya: Karya Anda, t.th.

Leden, Marpaung. Proses Penangan Perkara Pidana. Jakarta: Sinar Grafika, 1995.

Prakoso, Djoko. Alat Bukti dan Kekuatan Pembuktian di dalam Proses Pidana. Yogyakarta: Liberty, 1988.

Rusyd, Ibnu. Bid yatul Mujtahid. Juz III, terj. Abdurrahman, Haris Abdullah. Semarang: Asy-Syifa', t.t.

Sabiq, Sayyid. Fikih Sunnah. Juz 14, terj. Mudzakir AS. Bandung: AlMa'arif, 1998.

Fiqh As-Sunnah. Juz 13. Bandung: Al-Ma'arif, 1998.

Salam, Madkur M. Peradilan dalam Islam. terj. Imron AM. Surabaya: Bina Ilmu, 1993.

Soesilo, R. Kitab Undang-Undang Hukum Pidana (KUHP). Bogor: Politeia, t.th.

Sri, Soedewi. Hukum Perdata dan Hukum Benda. Yogyakarta: Liberty, 1981.

Syatha', Abu Bakar. I'ânah al-Ṭâlibîn. Juz III. Beirut: Dâr al-Kitâb 'Ilmiyyah, 1995.

Tim Fakultas Syari'ah IAIN Sunan Ampel. Petunjuk Teknis Penulisan Skripsi IAIN Sunan Ampel Surabaya, 2008.

Usman, Muslih. Kaidah-Kaidah Ushuliyah dan Fiqhiyah. Jakarta: Raja Grafindo Persada, 1997.

UU Kepolisian No.2 Th 2002

Bripka Supriyadi (Jabatan Penyidik di Polsek Wonocolo Surabaya). Wawancara. 
Irianto, Iptu Simun (WaKapolsekta Polsek Wonocolo Surabaya). Wawancara.

Wirjono, Prodjodikoro. Hukum Acara Pidana di Indonesia. Bandung: Sumur, 1990.

Yunus, Muhammad. Kamus Arab-Indonesia. Jakarta: Hidakarya Agung, 1990. 